\title{
ЧИННИКИ ВИНИКНЕННЯ ТА ПОСИЛЕННЯ ПРОЯВІВ ТРИВОГИ У ДІТЕЙ ДОШКІЛЬНОГО ВІКУ
}

\author{
Леся Вольнова \\ кандидат педагогічних наук, доцент, \\ доцент кафедри психосоматики та психологічної реабілітації \\ Національний педагогічний університет імені М. П. Драгоманова \\ 01601, Україна, м. Київ, вул. Пирогова, 9 \\ volnova1979@ukr.net, https://orcid.org/0000-0002-9647-8214 \\ Ганна Дьоміна \\ кандидат психологічних наук, доцент, \\ доцент кафедри психосоматики та психологічної реабілітації \\ Національний педагогічний університет імені М. П. Драгоманова \\ 01601, Україна, м. Київ, вул. Пирогова, 9 \\ a.a.demina@gmail.com, https://orcid.org/0000-0001-8319-3431
}

\begin{abstract}
Анотація
У статті наголошено актуальність проблеми формування емоційної сфери дошкільників, а, також, запобігання чи корекції негативних її проявів, зокрема, й проявів тривоги. Розкрито сутність тривоги як емоційного стану (переживання емоційного дискомфорту, пов'язаного 3 очікуванням неблагополуччя) та особистісної властивості (підвищеної схильності почуватися занепокоєним за будь-яких життєвих ситуацій). Проаналізовано підходи вчених до чинників дитячої тривоги та виокремлено найбільш поширені серед них пояснення тривожної поведінки дошкільників: 1) тривожність в дітей прямо пропорційна комфортності / стресовості життєвої ситуації; 2) тривожність дитини посилює постійне очікування можливих негативних наслідків (фізичного дискомфорту, болю, покарання, приниження) від якогось реального чи уявного впливу, ситуації, дії, людини тощо; 3) тривожність дітей тісно пов'язана 3 деструктивністю та нестабільністю поведінки і виховних впливів батьків, особливо матері; 4) наявність у анамнезі батьків, здебільшого матері, тривожних розладів може провокувати невиправдану тривожність у дітей; 5) порушення нейропсихологічної та нейрофізіологічної регуляції є віковою особливістю дошкільників та чинником їхньої тривожності.

За допомогою комплексу емпіричних методів (проєктивні методи, тестування, анкетування, метод самооцінки) досліджено рівень та особливості прояву тривоги (тривожності як особистісної риси) в дітей старшого дошкільного віку. 3'ясовано, що стан 3 тривожністю в дітей дошкільного віку не критичний, однак $є$ відносно стійка частка дітей (17,5\%), які мають за різними показниками високі прояви тривожності. Виявлено значущі кореляційні зв'язки між поведінковими проявами тривожності в дітей, рівнем їхнього психічного напруження та неадекватною самооцінкою. Констатовано, що не всі батьки готові прийняти інформацію про наявність у дитини проявів тривоги, а вихователі часто не вважають іiі свідченням проблемного розвитку дошкільника. У разі відсутності вчасної психопрофілактичної та психокорекційної роботи ці прояви можуть закріпитися та перерости у серйозні тривожні розлади.
\end{abstract}


Ключові слова: тривога, тривожність, діти дошкільного віку, чинники дитячої тривоги, поведінкові прояви тривожності.

\section{Вступ}

Проблема емоційного неблагополуччя дітей дошкільного віку не втрачає своєї актуальності як з огляду на ситуацію соціальної нестабільності в країні, постійне психічне перевантаження, що супроводжує сучасну людину в інформаційному суспільстві, так i тому, що дитинство - важливий період не лише для розвитку емоційної компетентності, але й загального соціального становлення підростаючої особистості. А тривога, підвищена занепокоєність, невпевненість, емоційна нестійкість, прояви яких можуть з'являтися ще в перші роки життя, перешкоджають соціальному та емоційному розвитку особистості впродовж усього дитинства. Такі дошкільники схильні уникати соціальних взаємодій i, як результат, можуть відчувати дефіцит у розвитку соціальних навичок, а тому вже під час навчання в школі оцінюються як менш просоціальні та більш замкнуті (Ale, Chorney, Brice $\&$ Morris, 2010). Окрім того, поява тривожних розладів у ранньому дитинстві, іноді у віці 2-3 років, підвищує ризик переростання їх у хронічні та збереження навіть у зрілому віці (Lazarus, Dodd, Majdandžić, Vente \& Hudson, 2016). Тобто, такі стани можуть, без надання відповідної психологічної допомоги як батькам, так і дітям, збільшувати ризик розвитку в останніх поганого самопочуття і проблем із психічним здоров'ям протягом усього життя. Означене посилює актуальність порушеної проблеми та вимагає іiі більш детального вивчення.

Аналізуючи феномен тривоги хочемо, передусім, зауважити, що до його розуміння $\epsilon$ два підходи, згідно з якими він розглядається або ж як емоційний стан, або ж як особистісна властивість. У першому випадку мова йде про «переживання емоційного дискомфорту, пов'язаного з очікуванням неблагополуччя, передчуттям небезпеки» (Прихожан, 2007: 12). Зазвичай такий стан $є$ ситуативним, а його прояви пов'язані 3 впливом соціально значущих для певної особи обставин. Для дошкільників це можуть бути ситуації спілкування з незнайомими дорослими, необхідність демонстрації певних знань чи умінь перед великою кількістю глядачів (як-от, на святкових ранках), виконання діяльності, яка потенційно пов'язана з очікуванням схвалення чи критики від батьків тощо.

У другому випадку частіше оперують поняттям «тривожність», що розглядається, як «індивідуальна психологічна особливість, яка проявляється в підвищеній схильності почуватися занепокоєним за будь-яких життєвих ситуацій, у тому числі тих, які взагалі не можуть викликати тривоги» (Томчук \& Томчук, 2018: 26).

Нами констатовано, що в закордонних дослідженнях здебільшого йде мова саме про тривогу як стан, який може переростати в тривожний розлад, тобто одну з форм психопатологіï, що поширена серед 5\% дітей (Lazarus, Dodd, Majdandžić, Vente \& Hudson, 2016: 784). Тоді як тривожність дослідники виявляють у середньому в $30 \%$ дошкільників, тобто в кожної третьої дитини рівень ії тривожності відрізняється від оптимальної норми, особливо, коли це стосується залучення в ситуації навчальної діяльності (Костина, 2007; Пасічніченко, 2012).

Серед психологічних проявів тривожності у дітей констатується внутрішня напруга, почуття безсилля, втрата почуття захищеності (особливо зі сторони батьків) та впевненості в собі, почуття певної соціальної ізольованості тощо. Часто ці переживання пов'язані 3 неадекватною самооцінкою: завищеною (коли за постійного очікування невдачі спрацьовує механізм компенсації) або ж заниженою (коли недостатність 
позитивного досвіду та демонстрація деструктивних стратегій взаємодії, як-от, конфліктності, агресивності, ще більше посилює почуття неповноцінності) (Міщенко \& Хавіна, 2017; Пасічніченко, 2012).

В. Горбатих, вивчаючи індивідуальні особливості самоставлення старшого дошкільника в структурі життєвих орієнтацій, зауважує, що тривожні переживання поступово набувають і зовнішніх проявів. Природно, що такі діти, прагнучи відновити внутрішній спокій, починають перебудовувати і свою поведінку, зокрема: проявляють схильність дотримуватися всіх (обгрунтованих чи необгрунтованих) вказівок дорослих; різко зменшують ініціативність i притаманну цьому віку пошуково-пізнавальну активність, все частіше прагнуть діяти лише за певним засвоєним алгоритмом (ухваленим дорослим); уникають будь-яких ситуацій, що вимагають прийняття хоча б якогось самостійного рішення; знання та способи дій засвоюють не лише формально, але й не прагнуть до будь-якого експериментування як у процесі виконання завдання, так і гри, обмежуються виконанням мінімально очікуваних вимог та найпростіших завдань (Горбатих, 2019). С. Томчук і М. Томчук переконані, що така надмірна дисциплінованість, слухняність мають захисний характер, тобто спрямовані не на те, щоби бути кращим, а, передусім, на те, щоб не стати гіршим, отримавши критику, зауваження, осуд (Томчук \& Томчук, 2018).

А. Пасічніченко емпірично підтвердила зв'язок високої тривожності із низьким статусом дитини в групі ровесників (Пасічніченко, 2012). Так, з одного боку, їхня занадто обережна або ж, навпаки, настирлива поведінка може відштовхувати однолітків, а, 3 іншого боку, обмеження кола спілкування та певна відчуженість часто провокують скарги таких дітей на те, що з ними «не дружать», а це, звісно, зовсім не сприяє прийняттю дитячим колективом, а ще більше поглиблює ситуацію відокремленості.

Попри те, що загалом тривожність, як один із наслідків необхідності постійної адаптації та пристосування до мінливих зовнішніх обставин, притаманна більшості людей, iii стійкий прояв у дитини є свідченням як певних порушень у особистісному розвитку, так і серйозною перепоною, що перешкоджає гармонійному розвитку в руслі вікових завдань. Такі діти частіше мають проблеми зі здоров'ям, постійна напруженість викликає хронічну втому, що суттєво дезорганізовує навчальну діяльність ще в дошкільному віці (Дмитріюк, 2015); надалі стійке емоційне неблагополуччя негативно впливає на основні системи навчальної взаємодії, викликаючи дискомфорт від самого перебування у школі, незадоволеність стосунками з вчителями, однокласниками, собою як суб'єктом навчання (Ставицька, 1998).

Загалом, здійснений теоретичний аналіз сучасних наукових досліджень засвідчив, що зарубіжними та вітчизняними вченими розкрито низку ключових аспектів прояву тривоги у дітей дошкільного віку, однак узагальненого підходу до її чинників поки ще не представлено, а емпіричні дані, що описують досліджуваний феномен, досить різняться, що й зумовило вибір мети статті.

Мета дослідження: теоретично обгрунтувати чинники дитячої тривоги та вивчити iii прояви в старших дошкільників на практиці. Завдання дослідження: 1) теоретично проаналізувати підходи вітчизняних і зарубіжних вчених щодо чинників дитячої тривоги; 2) здійснити емпіричне дослідження проявів тривоги (тривожності як особистісної риси) в дітей дошкільного віку та зіставити їх із наявними даними інших вчених.

\section{Методи дослідження}

У реалізації мети даної статті використано комплекс методів дослідження: 
теоретичні (аналіз психологічної літератури; систематизація, узагальнення, структурування даних) задля з'ясування сутності тривоги як феномена та виявлення теоретичних підходів до пояснення чинників дитячої тривоги; емпіричні (проєктивні методи, анкетування, тестування, метод самооцінки) 3 метою дослідження рівня та особливостей прояву тривоги (тривожності як особистісної риси) у дітей старшого дошкільного віку.

Вивчення проявів тривоги (тривожності як особистісної риси) відбувалося за допомогою комплексу методик, орієнтованих на:

1) самих дошкільників. Це були проєктивні методики: «Обери потрібне обличчя» (Р. Теммл, М. Доркі, В. Амен), адаптована для визначення індексу тривожності дитини старшого дошкільного віку, а також виявлення переважних ситуацій, у яких дитина відчуває дискомфорт (Михайлов \& Колеснік, 2016); «Будинок. Дерево. Людина», що дозволила з'ясувати загальне уявлення дитини про себе, ставлення до значущих для неї людей, сприйняття зовнішніх обставин, а також іiі тривожність, комунікабельність, агресивність тощо; а також «Сходинки», спрямована на виявлення рівня самооцінки дошкільника, ставлення до самого себе (Кононко, 1998);

2) батьків дошкільників. Зокрема, тест для батьків «Рівень тривожності та психічного напруження дитини» (О. Захаров) дозволив визначити, наскільки батьки помічають психологічний дискомфорт дитини та його інтенсивність (Захаров, 1982);

3) вихователів, котрі працюють із дітьми. «Анкета визначення рівня тривожності дошкільника» (Г. Лаврентьєва, Т. Титаренко) дозволила виявити рівень та особливості тривожності в дітей дошкільного віку, які відвідують дитячий садок (Лаврентьєва \& Титаренко, 1993).

\section{Результати та дискусії}

Виконуючи перше завдання нашого дослідження, ми проаналізувати підходи вчених щодо чинників дитячої тривоги та виокремили кілька найбільш поширених пояснень тривожної поведінки серед дошкільників. Зокрема:

1. Тривожність у дітей прямо пропоричійна комфортності/ стресовості життєвої ситуації. Так, К. Богрова, С. Валявко, Л. Костіна переконані, що високий рівень тривожності у дітей пов'язаний, передусім, із тим, що будь-яка ситуація невизначеності, необхідність контакту з незнайомими людьми та/або в нових умовах (що повністю характеризує перші дні, а то й тижні перебування дошкільника в дитячому закладі), звісно, викликає в них стрес (Богрова, 2017; Валявко, 2014; Костина, 2007). О. Козлюк і Н. Руденко допускають, що дитяча тривожність $є$ одним із наслідків внутрішнього конфлікту, який виникає в будь-якій незнайомій для дитини ситуації (Козлюк \& Руденко, 2017). Адже дитина втрачає значущого дорослого, який прямо чи опосередковано, але контролював та орієнтував іiі поведінку, а вона сама поки що не здатна зробити однозначний вибір. Також інші звуки, запахи, голоси тощо, що наповнюють нове середовище, в багатьох дітей теж не сприяють виникненню відчуття комфорту, а, найімовірніше, викликають питання на зразок, «Якщо мене мама любить, то чому лишила в такому місці?». Окрім того, згідно з даними Г. Прихожан, тривожність дошкільника може посилюватися саме в комунікативних ситуаціях, що цілеспрямовано створюються дорослими (як-от, вихователями). Діти підсвідомо відчувають, що їх перевіряють, контролюють. Це для них стрес - висловлювання стають або ж дуже тихими, уповільненими, або ж, навпаки, швидкими і квапливими (Прихожан, 2009). 
2. Тривожність дитини посилює постійне очікування можливих негативних наслідків (фізичного дискомфорту, болю, покарання, приниження) від якогось реального чи уявного впливу, ситуащії, діï, людини тощэ. У дошкільників активно розвивається уява, однак ще відсутнє критичне мислення. 3 огляду на це діти 3 певними типами темпераменту можуть демонструвати «гіпервізорне» тлумачення соціальних сигналів, тобто надмірно чутливо на них реагувати, що, звісно, буде посилювати їхню настороженість, соціальну самовіддачу й занепокоєння (Ale, Chorney, Brice \& Morris, 2010). Алкозей, П. Купер і К. Крезвелл також звертають увагу на притаманну дітям «упередженість інтерпретації» (тобто переоцінку небезпеки в навколишньому середовищі), яка змушує їх проявляти уникаючу поведінку, а також спричиняє тривожну чутливість, афективні стани навіть тоді, коли з'являється лише інформація про можливість потрапити в ситуацію, що може викликати фізичний дискомфорт (Alkozei, Cooper \& Creswell, 2014). В. Горбатих переконана, що «тривожні песимістичні очікування гальмують прояви комунікативної активності дитини, викликають у неї неадекватний емоційний відгук, призводять до розладу їі діяльності» (Горбатих, 2019: 69).

3. Тривожність дітей тісно пов'язана з деструктивністю та нестабільністю поведінки і виховних впливів батьків, особливо матері. Сутність деструктивної поведінки батьків полягає в тому, що вона призводить до руйнування емоційного контакту 3 оточенням, тобто атмосфера в сім’і не створює для дитини надійного психологічного захисту, комфорту та безпеки. Дослідниками простежено найбільш поширені негативні батьківські паттерни: недостатність уваги до дитини, ігнорування або нерозуміння іiі емоційних проявів (Дмитріюк, 2015); пригнічення поведінки дитини і незабезпечення надійної прив'язаності з боку матері; загальна негативна афективність матері (ShamirEssakow, Ungerer \& Rapee, 2005), а також певна iï зухвалість, як-от, «заперечення батьківської поведінки, у тому числі груба гра, що спонукає дітей виходити із зони комфорту й ризикувати» (Lazarus, Dodd, Majdandžić, Vente \& Hudson, 2016: 790). Водночас, цікавим є той факт, що зі сторони батька діти загалом нормально сприймають бурхливі, ризиковані ігри і навіть дії, оскільки він сам не вбачає ризиків у ситуації, яку створює, а тому й не хвилюється за неї. Тоді ж як матері в такий спосіб лише посилюють тривожні переживання дітей, вони переоцінюють негативний вплив як життєвих ситуацій, у які потрапляє дитина, так і свою щоденну поведінку щодо неї. Як результат, дитина, відчуваючи неспокій матері, сама стає неспокійною.

Нестабільність сімейного мікроклімату може бути викликана періодичними «нападами» почуття провини в матері. Наприклад, А. Апетроя, К. Кресвелл і К. Хілл виявили, що матері, котрі мають більш високий соціально-економічний статус та відсоток професійної зайнятості, частіше в стосунках із дитиною демонструють тривожні прояви (Apetroaia, Hill \& Creswell, 2015). Тобто вони приділяють менше часу дітям, а тому більше за них хвилюються. Рівень тривожності як матерів, так і дітей зростає, якщо останні єдині, пізні або не досить здорові (Томчук \& Томчук, 2018).

Окрім того, різка зміна стилю спілкування 3 дитиною, постійна невдоволеність 3 боку батьків ії вчинками, що поєднується то із заохочення до нової діяльності, то 3 критичним оцінним ставленням, викликають у неї емоційну дезорієнтацію, призводять до невпевненості в собі, невизначеності та безпорадності, напруги, необгрунтованого занепокоєння (Горбатих, 2019). Такі емоційні «гойдалки» вносять ще більшу нестабільність і в так нестійку емоційну сферу підростаючої особистості.

4. Наявність у анамнезі батьків, здебільшого матері, тривожних розладів може провокувати невиправдану тривожність у дітей. На перший погляд, тривожність батьків 
має посилювати їхню турботу про дитину, однак це не так. Справді, в батьків 3 актуальним тривожним розладом було помічено вищі показники почуття відповідальності за дії та благополуччя своєї дитини. Водночас, у матерів вони поєднувалися, по-перше, 3 менш теплою й більш нав'язливою поведінкою в стосунках із дитиною, надмірним контролем (надмірною регуляцією дій дітей, надмірним їх захистом та інструктуванням, навіть щодо того, як думати і відчувати, забороною прояву самостійності); по-друге, 3 моделюванням тривоги і вихованням у стані тривоги (опис будь-яких проблем як катастрофічних, нерозв'язних, небезпечних); а також зі слабкою та непослідовною підтримкою (Apetroaia, Hill \& Creswell, 2015). Причому вплив материнської тривожності не знижувався навіть після тривалої корекційної роботи з дітьми (Dougherty, Tolep, Bufferd, Olino, Dyson \& Traditi, 2013). Що ж до батьків-чоловіків із подібним розладом, то емпіричні дослідження не підтвердили припущення про такий зв'язок із тривогою дітей (Hudson, Dodd \& Bovopoulos, 2011).

Також, I. Остополець та Н. Шайдою було з'ясовано, що батьки, особливо матері, що мають стійкі характерологічні порушення (посилену тривожність, недовірливість) частіше реалізують виховання за типом гіперопіки, що поєднується з надмірно близькими, практично симбіотичними стосунками 3 дитиною, котра, як результат, повністю переймається тривожною налаштованістю батьків (Шайда \& Остополець, 2007).

5. Порушення нейропсихологічної та нейрофрізіологічної регуляиії $\epsilon$ віковою особливістю дошкільників та чинником їхньої тривожності. Щодо вказаного чинника, то тут поєднуються дві тенденції. 3 одного боку, науковці, наприклад, М. Міщенко та I. Хавіна, переконані, що «дитяча тривожність не пов'язана 3 якою-небудь певною ситуацією і проявляється майже завжди, супроводжує дитину в будь-якому виді діяльності, чи це навчальна або творча» (Міщенко \& Хавіна, 2017: 26). Тобто дитина маленька, в неї обмежений досвід, недостатньо сформовані навички, процес адаптації ще триває, а тому тривожність - це іiї звичний стан. Тут ми деякою мірою не погоджуємося 3 вченими, адже, якщо людину постійно «супроводжує» тривожність - це не значить, що мова йде лише про дитину, а також не всі діти відчувають психологічний дискомфорт у новій ситуації чи в певній діяльності, тобто проявляють тривожність.

Згідно 3 другою тенденцією, виникнення тривожності загалом, a, дитячої передусім, дослідники пов'язують із недостатньою адаптивністю психофізіологічних механізмів індивіда та, як наслідок, посиленням рівня активізації його нервової системи (Козлюк \& Руденко, 2017); з хронічною дисрегуляцією вегетативної нервової системи, що зумовлює негнучкість вегетативних реакцій як у ситуації стресу, так і без нього (Friedman, 2007; Депутат, 2011).

Щодо другого завдання нашої наукової роботи, то до емпіричного дослідження було залучено 40 дітей - вихованців трьох старших груп «звичайного» (не спеціалізованого) дошкільного закладу м. Києва. 3 кожної групи ми виокремили 12-15 осіб віком 5-6 років у такий спосіб, щоб охопити дітей, які будуть становити порівняно однорідну вибірку. Зокрема, ми працювали лише з дітьми, котрі займаються за однаковою програмою щодо підготовки до шкільного навчання, тобто не відвідують занять, наприклад, у «маленькій школі», розвивальному центрі тощо, оскільки це додатковий стресор, що може підвищити тривожність. Вихованці були різної статті, з родин із різною матеріальною забезпеченістю, з різним складом і кількістю членів. Ці змінні в рамках цього етапу нашого дослідження окремо не вивчалися.

Спочатку нами була проведена проєктивна методика «Обери потрібне обличчя» 
(Р. Теммл, М.Доркі, В.Амен), за результатами якої винятково високі показники тривожності ми виявили щодо ситуацій «Вкладання спати на самоті», «Сварка», «Гра зі старшими дітьми» та «Ігнорування». Розглянемо докладніше. Так, найбільша кількість виборів припала на ситуацію «Спати на самоті» (40\%). Ми це пояснюємо віковими особливостями розвитку мислення. Дітям здебільшого доступний поки що лише наочнообразний тип мислення, вони ще не здатні мислити абстрактно (символами) і логічно. Дитяча фантазія в цьому віці дуже розвинена, а несвідомі образи, які з'являються в снах, діти здатні прикрашати й додумувати свідомо. Тому самому спати страшно.

Другою за значущістю стала ситуація «Сварка» (30\%). Дітям загалом важко адекватно оцінити те, що відбувається, і навіть найбільш розвинені діти, спостерігаючи сварку, швидше за все, подумають, що дорослі їх не люблять. У душі дитини зародиться страх, що саме вона винна в тому, що відбувається. I, як результат, - підвищується тривожність.

Ще одна тривожна ситуація - це «Гра зі старшими дітьми» (10\%). Реакція на цю ситуацію була виявлена лише в дітей, у яких $є$ проблеми в спілкуванні зі старшими дітьми, страх контакту 3 людьми, що може говорити загалом про проблеми їхньої соціалізації. Якщо у дитини є багатий досвід спілкування, а значущі дорослі грамотно вводять її у світ людських взаємин, то соціалізація, як правило, проходить більш успішно.

Й останньою за значущістю стала ситуація «Ігнорування» (10\%). Ігнорування, справді, дуже травмує. Батьки ігнорують дитину як усвідомлено, так і несвідомо: усвідомлене ігнорування, зазвичай, трапляється в ситуації, коли значущий дорослий карає і просто перестає розмовляти з дитиною. Несвідоме ігнорування, як правило, відбувається тоді, коли в батьків немає ресурсу на спілкування 3 дитиною; немає сил цікавитися іiі життям, не хочеться зрозуміти. Іноді мама або тато просто присутні поруч із дитиною, водночас, практично не спілкуються, не грають і не взаємодіють.

Загалом, за цією методикою нами виявлено високий індекс тривожності в 6 досліджуваних дітей (15\%), середній - у 19 (47,5\%), низький - у 15 (37,5\%). Ці результати кардинально розходяться з даними, представленими О. Козлюк і Н. Руденко за 2015 р. Вчені підкреслюють стійке зростання тривоги в дошкільників та, спираючись на дослідження 3. Кісарчук й Я. Омельченко, зауважують іiі на високому рівні у 72\% опитаних (Козлюк \& Руденко, 2017: 133). Ми це пояснюємо складними політичними та економічними умовами в країні, які були в той час, швидким зростанням частки внутрішньо переміщених осіб, а також учасників бойових дій. Відтоді пройшло вже 5 років, за які відбулися політичні та економічні зміни, також дещо стабілізувалася й ситуація.

Досить інформативною виявилася проєктивна методика «Будинок. Дерево. Людина». Узагальнення окремих показників дозволило констатувати високий рівень тривожності в 6 (15\%) дітей, середній - у 20 (50\%) і низький - у 14 (35\%) дітей. Проаналізувавши малюнки дітей із високим рівнем тривожності, ми виявили деякі характерні особливості. Зокрема, на багатьох малюнках є хмари, які, вважаємо, можуть вказувати на загальне почуття тривожності, пов'язане з взаємовідносинами з оточуючими. Також у будинку було виокремлено багато деталей, обмежено простір, застосовано штрихування та багато стирання, багато ліній було зі значним натиском, а також досить товста лінія фундаменту. У двох дітей дерева були мертві, без листя (що може свідчити про наявність почуттів неповноцінності, непристосованості, неспроможності, провини), у 
трьох - 3 дуплом (що свідчить про травму в анамнезі), в однієї дівчинки дерево було спиляне (можливий варіант ототожнення дерева i членів сім’ï). Якщо поглянути на зображення людини таких дітей, то можна побачити надто заштриховане волосся, в однієї дитини заштриховане обличчя, що може свідчити про негативне самопочуття. Деякі діти робили особливий акцент на очах - їхньому розмірі, штрихуванні зі значним натиском райдужки або всіх очей (певні страхи).

Загалом, для багатьох тривожних дітей було притаманне замашне, недбале штрихування всього малюнка або будь-якої його частини. В однієї дитини виявлено надмірну кількість деталей - ознака того, що вона охоплена тривогою й намагається придушити це почуття. Спостерігалися також численні самовиправлення, що може говорити про надмірну невпевненість дітей, боязнь зробити щось не так. Після стирання, замість однієї лінії з'являється декілька. Малюнки (дерево й будинок) у двох дітей не помістилися на аркуші, тоді ж як сама людина була зображена маленькою в нижній частині аркуша. Звісно, що самі зображення $є$ лише опосередкованим свідченням тривоги, однак дозволяють виявити деякі приховані переживання дітей.

За допомогою методики «Сходинки» ми підтвердили припущення про те, що діти 3 високим рівнем тривожності досить невпевнені в собі та своїх діях, мають нестійку самооцінку. Так, адекватна самооцінка була виявлена у 12 (30\%) осіб; завищену самооцінку мають 15 дітей (37,5\%) та занижену 13 (32,5\%). Це може бути також і віковим проявом, оскільки особистість дошкільника ще не сформована. Отримані дані загалом співвідносяться з таким же дослідженням М. Міщенко та I. Хавіної (Міщенко \& Хавіна, 2017). Водночас, А. Пасічніченко наводить більш критичні результати: у 54\% дітей нею зафіксовано завищену самооцінку, у 24\% - занижену і лише у 22\% - адекватну самооцінку (Пасічніченко, 2012). Можливо, це пов'язано з тим, що дослідниця зробила акцент на певні види діяльності, в які залучаються діти, що може бути окремим чинником тривожності та потребує додаткового вивчення.

Задля уточнення отриманих даних ми провели опитування батьків за допомогою тесту «Рівень тривожності та психічного напруження дитини» (за О. Захаровим). Батькам була чітко подана інструкція, усі вони погодилися заповнили тест і досить швидко принесли результати для обробки. Здебільшого батьки цікавилася результатами, що свідчить про їхню небайдужість та турботу про психічне здоров'я дітей. Згідно 3 відповідями батьків, незначні відхилення, що проявляються як вікові особливості розвитку дитини, зафіксовано в 32,5\% дітей; здебільшого діти мають низький рівень психічного напруження (40\%), хоча й потребують уваги до себе. Водночас, була виокремлена і група дітей, поведінкою яких батьки досить стурбовані. Щодо них було констатовано нервовий розлад, середній рівень психоемоційного напруження у 12,5\% дітей, невроз був чи буде найближчим часом - у 10\% досліджуваних дошкільників, а також невроз, високий рівень психоемоційного напруження - у 5 \% дітей. Тобто, 27,5\% дітей мають поведінкові прояви, що свідчать про актуальний розвиток чи значний ризик розвитку неврозу. На жаль, більшість батьків, у чиїх дітей виявили відповідні невротичні розлади, не надали отриманим результатам належного значення. Це може бути як варіантом самозахисту і заперечення проблеми, так і свідчити, можливо, про те, що дитина виховується в сім’'і, де немає згоди між дорослими з питань виховання, що вимоги щодо неї непослідовні, а вона постійно перебуває в стані невизначеності та стресу.

Діагностична робота 3 вихователями здійснювалася за допомогою «Анкети визначення рівня тривожності дошкільника» (Г. Лаврентьєва, Т. Титаренко). Слід 
зауважити, що педагогічні працівники вказали, що в тривожних дітей вони частіше спостерігають страх перед невідомим і новим, у результаті чого дошкільники $\epsilon$ безініціативними в житті дитячої групи. Водночас, такі діти мають і умовно позитивні якості (для батьків і педагогів) - слухняність, покірність, скромність, сором'язливість, частіше намагаються чітко виконувати вимоги дорослих i, що головне, практично не порушують дисципліну. Звісно, така дитина рідше викликає клопоти у вихователів, а тому часто вони й не бачать потреби якось змінювати їі поведінку. Загалом вихователі констатували, що низький рівень тривожності мають 12 дітей $(30 \%)$, середній рівень - 23 дитини $(57,5 \%)$ та високий рівень - 5 (12,5\%) дітей. За цією методикою наші результати збігаються з аналогічним дослідженням, проведеним С. Томчуком та М. Томчуком. Окрім того, дослідники звернули увагу, що педагогічні працівники більш чітко виокремлюють дітей, які, на їхню думку, мають виражену тривожність (12-16\%), тоді ж як лише 2 \% батьків визнали у своїх дітей явну тривожність (Томчук \& Томчук, 2018). Це теж підтверджує висловлене нами вище припущення про те, що батьки намагаються дистанціюватися від проблеми, використовуючи стратегії уникнення та заперечення. У вихователів же такої потреби немає, тому вони можуть більш об'єктивно оцінити дитину.

Узагальнення отриманих даних засвідчило, що за чотирма методиками 17,5\% досліджуваних дошкільників мають достатньо високий рівень тривожності, тобто потребують залучення до корекційної роботи та зниження тривожності в повсякденній діяльності. Серед ситуацій, що посилюють тривожність, нами зауважено такі: різка зміна звичних оточення та обставин, потенційна агресія з боку оточуючих та старших, самотність (зокрема, ризик розлуки з матір'ю), авторитарне ставлення батьків, ізоляція 3 боку однолітків. Усі діти дошкільного віку в перерахованих ситуаціях очікують чогось неприємного, але очікування тривожних дітей значно більш негативні, ніж нетривожних.

Для перевірки взаємозв'язків між отриманими результатами за різними методиками нами було використано кореляційний аналіз з обчисленням коефіцієнта кореляції рангів Спірмена. Була виявлена значуща кореляція $(\mathrm{p}<0,01)$ між високим рівнем тривожності за «Анкетою визначення рівня тривожності дошкільника» та:

- заниженою самооцінкою за методикою «Сходинки» $(0,262)$;

- показником «невроз був чи буде найближчим часом» за тестом для батьків «Рівень тривожності та психічного напруження дитини» $(0,371)$;

- високим індексом тривожності за методикою «Обери потрібне обличчя» $(0,548)$;

- зворотна кореляція 3 показником «відхилення незначні й проявляються як вікові особливості розвитку дитини» за тестом для батьків «Рівень тривожності та психічного напруження дитини» $(-0,433)$.

Вважаємо, що можна говорити про те, що чим нижча самооцінка, тим вищий рівень тривожності, та чим більше дитина схильна до проявів неврозу, тим швидше в неї проявляється тривожність, а ті діти, які не мають невротичних відхилень, не мають i підвищеного рівня тривожності.

\section{Висновки}

Звісно, представлений вище перелік чинників виникнення тривоги в дітей не $\epsilon$ вичерпним та може доповнюватися і варіюватися з огляду на вік дитини чи нові емпіричні дані. Водночас, орієнтація саме на комплекс чинників, на нашу думку, дозволить, поперше, оптимізувати як процес діагностики тривожності дошкільників, так і планування 
змісту профілактичної чи психокорекційної роботи як із ними, так i, в деяких випадках, передусім із батьками. А, по-друге, з огляду на різні джерела «походження» тривоги доцільним буде залучення до допомоги дитині не лише фахівця-психолога, але й, можливо, психотерапевта чи невропатолога, соціального працівника.

Наведені емпіричні дані свідчать, що стан із тривожністю в дітей дошкільного віку, хоча й не критичний, однак є порівняно стійка частка дітей (у нас це 17,5\%), які мають за різними показниками високі прояви тривожності. Водночас, це лише старші дошкільники i стресорів поки на них впливає менше. Якщо ж отримані дані не стануть для батьків і педагогічного колективу мотивом для початку відповідної роботи 3 дітьми в цьому напрямі, то в шкільні роки не лише зросте частка дітей із такими проявами, але й у багатьох дошкільників вони можуть закріпитися і перерости в серйозні тривожні розлади.

3 огляду на вищезазначене, перспективи подальших досліджень вбачаємо в розробці та апробації комплексної програми корекції тривожності в дітей дошкільного віку із залученням до неї всіх суб’єктів педагогічного процесу.

\section{Література}

1. Богрова, Х.Б. (2017). Аналіз теоретико-емпіричних досліджень просодичного компоненту мовлення та індивідуально-психологічних особливостей дітей дошкільного віку. Психолінгвістика, 21(1), 12-23. Режим доступу : https://psycholingjournal.com/index.php/journal/article/view/38

2. Валявко, С.М. (2014). Эмоциональные переживания в ситуации речевого общения у старших дошкольников с нарушениями речевого развития. Системная психология $u$ сочиология: Всероссийское периодчческое издание, научно-практический журнал, 2(10), Режим доступа : http://systempsychology.ru/journal/2014 10/190-valyavko-s-memocionalnye-perezhivaniya-v-situacii-rechevogo-obscheniya-u-starshih-doshkolnikov-snarusheniyami-rechevogo-razvitiya.html

3. Горбатих, В.В. (2019). Індивідуальні особливості самоставлення старшого дошкільника в структурі життєвих орієнтацій (Дис. канд. психол. наук). Київ.

4. Депутат, Н.I. (2011). Передумови виникнення тривожності у дітей дошкільного віку із затримкою психічного розвитку. Педагогічна освіта: теорія і практика, 8, 390-395. Режим доступу : http://nbuv.gov.ua/UJRN/znppo 2011869

5. Дмитріюк, Н.С. (2015). Проблема тривожності у старших дошкільників: деякі емпіричні кореляти та індикатори. Актуальні проблеми психологіi, 10(27), 133-143. Режим доступу : http://appsychology.org.ua/data/jrn/v10/i27/14.pdf

6. Захаров, А. (1982). Психотерапия неврозов у детей и подростков. Москва.

7. Козлюк, О.А., \& Руденко, Н.М. (2017). Особливості розвитку тривожності дошкільників у системі дитячо-батьківських взаємин. Проблеми сучасної психологіï. Збірник наукових пращь К-ПНУ імені Івана Огієнка, Інституту психології імені Г.С.Костюка НАПН України, 36, 131-145. https://doi.org/10.32626/2227-6246.2017$\underline{36 . \% \mathrm{p}}$

8. Кононко, О.Л. (1998). Соціально-емоційний розвиток особистості (в дошкільному дитинстві). Київ : Освіта.

9. Костина, Л.М. (2007). Лонгитюдное исследование эффективности психологической коррекции детской тревожности. Ученые записки Санкт-Петербургского государственного университета психологии и социальной работы, 2, 37-40.

10. Лаврентьєва, Г.П., \& Титаренко, Т.М. (1993). Практична психологія для вихователів. Київ : ВІПОЛ.

11. Михайлов, Б.В., \& Колеснік, Н.М. (2016). Модифікація тесту тривожності Р. Теммл, М. Доркі, В. Амен (Методика «Обери потрібне обличчя») для поглибленого дослідження тривожності у дітей дошкільного віку. Чоловіче здоров'я, гендерна та психосоматична медицина. Украӥнський журнал, 2(04), 41-48. Режим доступу : http://ujmh.org/?op $=1 \& \mathrm{z}=46 \& \mathrm{i}=6$ 
12. Міщенко, М.П., \& Хавіна, І.В. (2017). Психологічні особливості страхів і тривожності у дітей дошкільного віку. О.Г. Романовський (Ред.), Проблеми та перспективи формування начіональної гуманітарно-технічної еліти : матеріали міжнародної науково-практичної конферениї студентів, аспірантів та молодих вчених «Психолого-педагогічні аспекти формування управлінського потениіалу сучасної молоді: теорія і практика», (21 жовтня 2016 р.). (Вип. 46 (50), с. 18-31). Харків: НТУ «XПI». Режим доступу : http://repository.kpi.kharkov.ua/bitstream/KhPIPress/29201/1/Elita_2017 46 Mishchenko_Psykholohichni.pdf

13. Пасічніченко, А.В. (2012). Особливості тривожності дітей дошкільного віку. Вісник Харківського наџіонального педагогічного університету імені Г.С. Сковороди. $\begin{array}{llll}\text { Психологія, } & 49, & 93-95 . & \text { Режим доступу }\end{array}$ http://dspace.pnpu.edu.ua/handle/123456789/10474

14. Прихожан, А.М. (2009). Психология тревожности: дошкольный и школьный возраст. Санкт-Петербург : Питер.

15. Ставицька, С.О. (1998). Психолого-педагогічні умови подолання особистісної тривожності у дітей молодшого шкільного віку. (Автореф. дис. канд. психол. наук). Київ.

16. Томчук, С.М., \& Томчук, M.I. (2018). Психологія тривоги, страху та агресї особистості в освітньому прочесі (Монографія). Вінниця: КВНЗ «ВАНО».

17. Шайда, Н.П., \& Остополець, І.Ю. (2007). Феномен емоційної кризи дітей 6-7 років. Проблеми екстремальної та кризової психологї̈, 2, 283-291. Режим доступу: http://nuczu.edu.ua/sciencearchive/ProblemsOfExtremeAndCrisisPsychology/vol2/34.pdf

18. Ale, Ch.M., Chorney D.B., Brice, Ch.S., \& Morris, T.L. (2010). Facial affect recognition and social anxiety in preschool children. Early Child Development and Care, 180 (10), 13491359. https://doi.org/10.1080/03004430903059318

19. Alkozei, A., Cooper, P.J., \& Creswell, C. (2014). Emotional reasoning and anxiety sensitivity: Associations with social anxiety disorder in childhood. Journal of Affective Disorders, 152-154 (Jan.), 219-228. https://doi.org/10.1016/j.jad.2013.09.014

20. Apetroaia, A., Hill, C., \& Creswell, C. (2015). Parental responsibility beliefs: associations with parental anxiety and behaviours in the context of childhood anxiety disorders. Journal of Affective Disorders, 188 (1 Dec.), 127-133. https://doi.org/10.1016/j.jad.2015.08.059

21. Dougherty, L.R., Tolep, M.R., Bufferd, S.J., Olino, Th.M., Dyson, M., \& Traditi, J. (2013). Preschool anxiety disorders: comprehensive assessment of clinical, demographic, temperamental, familial, and life stress correlates. Journal of Clinical Child \& Adolescent Psychology, 42(5), 577-589. https://dx.doi.org/10.1080\%2F15374416.2012.759225

22. Friedman, B.H. (2007). An autonomic flexibility-neurovisceral integration model of anxiety

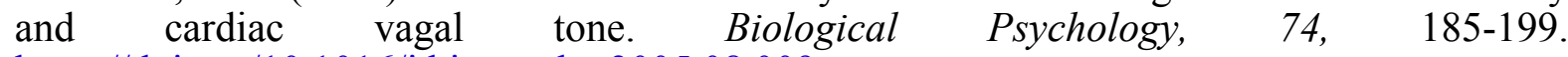
https://doi.org/10.1016/i.biopsycho.2005.08.009

23. Hudson, J.L., Dodd, H.F. \& Bovopoulos, N. (2011). Temperament, family environment and anxiety in preschool children. Journal of Abnormal Child Psychology, 39 (7), 1573-2835. https://doi.org/10.1007/s10802-011-9502-x

24. Lazarus, R.S., Dodd, H.F., Majdandžić, M., Vente, W.de, \& Hudson, J.L. (2016). The relationship between challenging parenting behaviour and childhood anxiety disorders.
Journal
of Affective
Disorders,
190
(15 Jan.),
784-791. https://doi.org/10.1016/j.jad.2015.11.032

25. Shamir-Essakow, G., Ungerer, J.A, \& Rapee, R.M. (2005). Attachment, behavioral inhibition, and anxietyin preschool children. Journal of Abnormal Child Psychology, 33 (2, April), 131-143. https://doi.org/10.1007/s10802-005-1822-2

\section{References}

1. Bohrova, K.B. (2017). Analiz teoretyko-empirychnykh doslidzhen prosodychnoho komponentu movlennia ta indyvidualno-psykholohichnykh osoblyvostei ditei doshkilnoho viku 「Analysis of the theoretical and empirical studies of the prosodic component of speech and the individual and psychological peculiarities of pre-school children]. Psykholinhvistyka - Psycholinguistics, 21(1), 12-23. Retrieved from https://psycholingjournal.com/index.php/journal/article/view/38 [in Ukrainian]. 
2. Valyavko, S.M. (2014). Emotsionalnye perezhivaniya v situatsii rechevogo obshcheniya u starshikh doshkolmkov s narusheniyami rechevogo razvitiya [Emotional experiences in a situation of speech communication in older preschool children with speech development disorders]. Sistemnaja psihologija i sociologija: Vserossijskoe periodicheskoe izdanie, nauchno-prakticheskij zhurnal - Systems Psychology and Sociology: All-Russian periodical scientific and practical journal, 2(10), Retrieved from http://systempsychology.ru/journal/2014 10/190-valyavko-s-m-emocionalnyeperezhivaniya-v-situacii-rechevogo-obscheniya-u-starshih-doshkolnikov-s-narusheniyamirechevogo-razvitiya.html [in Russian].

3. Horbatykh, V.V. (2019). Indyvidual'ni osoblyvosti samostavlennya starshoho doshkil'nyka v strukturi zhyttyevykh oriyentatsiy [Individual peculiarities of self prescribing of the senior preschooler in the structure of life orientations] Candidate's thesis. Kyyiv [in Ukrainian].

4. Deputat, N.I. (2011.) Peredumovy vynyknennia tryvozhnosti u ditei doshkilnoho viku iz zatrymkoiu psykhichnoho rozvytku [Prerequisites for anxiety in preschool children with mental retardation]. Pedahohichna osvita: teoriia i praktyka-Pedagogical education: theory and practice, 8, 390-395. Retrieved from http://nbuv.gov.ua/UJRN/znppo 2011869 [in Ukrainian 7 .

5. Dmytriiuk, N.S. (2015). Problema tryvozhnosti u starshykh doshkilnykiv: deiaki empirychni koreliaty ta indykatory [The problem of anxiety in the senior preschool age: some empirical correlations and indicators]. Aktualni problemy psykholohii-Actual problems of psychology, 10(27), 133-143. Retrieved from http://appsychology.org.ua/data/jrn/v10/i27/14.pdf [in Ukrainian 7 .

6. Zakharov, A. (1982). Psikhoterapiya nevrozov u detey i podrostkov [Psychotherapy of neurosis in children and adolescents7. Moscow [in Russian].

7. Kozliuk, O.A., \& Rudenko, N.M. (2017). Osoblyvosti rozvytku tryvozhnosti doshkilnykiv u systemi dytiacho-batkivskykh vzaiemyn [Features of preschoolers' anxiety development in the system of child-parent relationship]. Problemy suchasnoi psykholohii. Zbirnyk naukovykh prats K-PNU imeni Ivana Ohiienka, Instytutu psykholohii imeni H.S.Kostiuka NAPN Ukrainy - Problems of Modern Psychology : Collection of research papers of Kamianets-Podilskyi Ivan Ohienko National University, G.S. Kostiuk Institute of Psychology at the NAPSU, 36, 131-145. https://doi.org/10.32626/2227-6246.2017-36.\%p [in Ukrainian].

8. Kononko, O.L. (1998). Sotsial'no-emotsiynyy rozvytok osobystosti (v doshkil'nomu dytynstvi) [Socio-emotional development of the individual (in preschool childhood)]. Kyyiv : Osvita [in Ukrainian].

9. Kostina, L.M. (2007). Longityudnoe issledovame effektivnosti psikhologicheskoy korrektsii detskoy trevozhnosti [Longitudinal study of the effectiveness of psychological correction of children's anxiety]. Uchenye zapiski Sankt-Peterburgskogo gosudarstvennogo universiteta psihologii $i$ social'noj raboty - Scientific notes of the St. Petersburg State University of Psychology and Social Work, 2, 37-40 [in Russian].

10. Lavrent'yeva, H.P., \& Tytarenko, T.M. (1993). Praktychna psykholohiya dlya vykhovateliv [Practical Psychology for Educators]. Kyyiv : VIPOL [in Ukrainian].

11. Mykhailov, B.V., \& Kolesnik, N.M. (2016). Modyfikatsiia testu tryvozhnosti R. Temml, M. Dorki, V. Amen (Metodyka «Obery potribne oblychchia») dlia pohlyblenoho doslidzhennia tryvozhnosti u ditei doshkilnoho viku 「Modification of anxiety test R. Teml, M. Dorki, V. Amen («Choose the right face» technique) for in-depth study of anxiety in preschool children]. Choloviche zdorovia, henderna ta psykhosomatychna medytsyna. Ukrainskyi zhurnal - Men's health, gender and psychosomatic medicine. Ukrainian Journal, 2(04), 4148. Retrieved from http://uimh.org/?op=1\&z=46\&i=6 [in Ukrainian].

12. Mishchenko M.P., \& Khavina I.V. Psykholohichni osoblyvosti strakhiv i tryvozhnosti u ditei doshkilnoho viku [Psychological especially the fear and anxiety in preschool children]. In O.H. Romanovskyi (Ed.), Proceedings from PPAFUPSM'2017: Problemy ta perspektyvy formuvannia natsionalnoi humanitarno-tekhnichnoi elity : materialy mizhnarodnoi naukovopraktychnoi konferentsii studentiv, aspirantiv ta molodykh vchenykh: "Psykholohopedahohichni aspekty formuvannia upravlinskoho potentsialu suchasnoi molodi: teoriia $i$ praktyka»-Problems and prospects of formation of the national humanitarian-technical elite: materials of the international scientific-practical conference of students, graduate 
students and young scientists: «Psychological and pedagogical aspects of the formation of managerial potential of modern youth: theory and practice», (October 21, 2016), (Vyp. 46 (50), pp.18-31). Kharkiv: NTU «KPI». Retrieved from http://repository.kpi.kharkov.ua/bitstream/KhPI-

Press/29201/1/Elita 201746 Mishchenko Psykholohichni.pdf [in Ukrainian].

13. Pasichnichenko, A.V. . (2012). Osoblyvosti tryvozhnosti ditei doshkilnoho viku [Features of anxiety of preschool children]. Visnyk Kharkivskoho natsionalnoho pedahohichnoho universytetu imeni H. S. Skovorody. Psykholohiia - Bulletin of the GS Skovoroda Kharkiv National Pedagogical University. Psychology, 49, 93-95. Retrieved from http://dspace.pnpu.edu.ua/handle/123456789/10474 [in Ukrainian].

14. Prikhozhan, A.M. (2009). Psikhologiya trevozhnosti: doshkolmy $i$ shkolnyy vozrast [Psychology of anxiety: preschool and school age]. Saint Petersburg : Piter [in Russian].

15. Stavytska, S.O. (1998). Psychological and pedagogical conditions to overcome personal anxiety with younger school-age children 「Psykholoho-pedahohichni umovy podolannya osobystisnoyi tryvozhnosti u ditey molodshoho shkil'noho viku]. Extended abstract of Candidate's thesis. Kyyiv : VIPOL [in Ukrainian].

16. Tomchuk, S.M., \& Tomchuk, M.I. (2018). Psykholohiya tryvohy, strakhu ta ahresiyi osobystosti $v$ osvitn'omu protsesi /Psychology of anxiety, fear and aggression of the individual in the educational process]. Vinnytsya : KVNZ «VANO» [in Ukrainian].

17. Shaida, N.P., \& Ostopolets, I.Iu. (2007). Fenomen emotsiinoi kryzy ditei 6-7 rokiv 「The phenomenon of emotional crisis of children 6-7 years]. Problemy ekstremalnoi ta kryzovoi psykholohii - Problems of extreme and crisis psychology, 2, 283-291. Retrieved from http://nuczu.edu.ua/sciencearchive/ProblemsOfExtremeAndCrisisPsychology/vol2/34.pdf [in Ukrainian].

18. Ale, Ch.M., Chorney D.B., Brice, Ch.S., \& Morris, T.L. (2010). Facial affect recognition and social anxiety in preschool children. Early Child Development and Care, 180(10), 13491359. https://doi.org/10.1080/03004430903059318

19. Alkozei, A., Cooper, P.J., \& Creswell, C. (2014). Emotional reasoning and anxiety sensitivity: Associations with social anxiety disorder in childhood. Journal of Affective Disorders, 152-154 (Jan.), 219-228. https://doi.org/10.1016/j.jad.2013.09.014

20. Apetroaia, A., Hill, C., \& Creswell, C. (2015). Parental responsibility beliefs: associations with parental anxiety and behaviours in the context of childhood anxiety disorders. Journal of Affective Disorders, 188 (1 Dec.), 127-133. https://doi.org/10.1016/j.jad.2015.08.059

21. Dougherty, L.R., Tolep, M.R., Bufferd, S.J., Olino, Th.M., Dyson, M., \& Traditi, J. (2013). Preschool anxiety disorders: comprehensive assessment of clinical, demographic, temperamental, familial, and life stress correlates. Journal of Clinical Child \& Adolescent Psychology, 42(5), 577-589. https://dx.doi.org/10.1080\%2F15374416.2012.759225

22. Friedman, B.H. (2007). An autonomic flexibility-neurovisceral integration model of anxiety and cardiac vagal tone. Biological Psychology, 74, 185-199. https://doi.org/10.1016/i.biopsycho.2005.08.009

23. Hudson, J.L., Dodd, H.F. \& Bovopoulos, N. (2011). Temperament, family environment and anxiety in preschool children. Journal of Abnormal Child Psychology, 39(7 Oct.), 1573-2835. https://doi.org/10.1007/s10802-011-9502-x

24. Lazarus, R.S., Dodd, H.F., Majdandžić, M., Vente, W.de, \& Hudson, J.L. (2016). The relationship between challenging parenting behaviour and childhood anxiety disorders. Journal of Affective Disorders, $190 \quad$ (15 $\quad$ Jan.), $784-791$. https://doi.org/10.1016/j.jad.2015.11.032

25. Shamir-Essakow, G., Ungerer, J.A, \& Rapee, R.M. (2005). Attachment, behavioral inhibition, and anxietyin preschool children. Journal of Abnormal Child Psychology, 33(2, April), 131-143. https://doi.org/10.1007/s10802-005-1822-2 


\title{
FACTORS OF EMERGENCY AND INCREASED ANXIETY MANIFASTATIONS IN PRESCHOOL-AGE CHILDREN Lesia Volnova \\ PhD in Pedagogics, Associate Professor, Associate Professor, Department of Psychosomatics and Psychological Rehabilitation National Pedagogical Dragomanov University \\ 9, Pyrohov Str., Kyiv, Ukraine, 01601 \\ volnova1979@ukr.net, https://orcid.org/0000-0002-9647-8214

\author{
Hanna Domina \\ PhD in Psychology, Associate Professor, \\ Associate Professor, Department of Psychosomatics and Psychological Rehabilitation \\ National Pedagogical Dragomanov University \\ 9, Pyrohov Str., Kyiv, Ukraine, 01601 \\ a.a.demina@gmail.com, https://orcid.org/0000-0001-8319-3431
}

\begin{abstract}
The article emphasizes the urgency of the problem of forming the emotional sphere of preschoolage children, as well as the prevention or correction of its negative manifestations, including the manifestations of anxiety. The essence of anxiety is revealed as an emotional state (experiencing emotional discomfort associated with the expectation of troubles) and personal quality (increased tendency to feel disturbed in any life situations). The approaches of the scientists to the factors of child anxiety are analyzed and the most common explanations among them of the anxious behavior of preschool-age children are singled out: 1) children anxiety is directly proportional to the comfort / stress of the life situation; 2) the anxiety of the child is increased by the constant expectation of possible negative consequences (physical discomfort, pain, punishment, humiliation) of any real or imagined influence, situation, action, person, etc; 3) child anxiety is closely linked to the destructive and unstable behavior and parental influence, especially mother's; 4) having a positive family history, mostly mother's, of anxiety disorders existence can provoke unjustified anxiety in children; 5) disturbance of neuropsychological and neurophysiological regulation is an age-old feature of preschoolers and a factor of their anxiety.

Using a set of empirical methods (projective methods, testing, questioning, self-assessment method), the level and features of anxiety (anxiety as a personality trait) in older preschool-age children were investigated. It has been found that the amount of preschool-age children with anxiety is not critical, but there is a relatively stable proportion of children $(17.5 \%)$ who have different manifestations of high anxiety. Significant correlation links were found between children behavioral anxiety, their level of mental distress, and inadequate self-esteem. It has been stated that not all parents are ready to accept information about the child's anxiety, and nursery teachers often do not consider it to be the evidence of problematic preschooler development. In the absence of timely psychoprophylactic and psycho-correction work, these manifestations can become established and develop into serious anxiety disorders.
\end{abstract}

Keywords: anxiety, preschool children, the factors of children anxiety, behavioral manifestations of anxiety. 